\title{
Overcoming Interspecific Hybrid Sterility in Lilium ${ }^{1}$
}

\author{
Yoshito Asano \\ Faculty of Agriculture, Hokkaido University, Sapporo 060
}

\begin{abstract}
Summary
For the purpose of overcoming interspecific hybrid sterility in Lilium, the following methods were attempted: 1) Further use of embryo culture in the cross of $F_{1}$ and 2) Use of amphidiploids induced from $F_{1}$. When $F_{1}$ hybrids were used as female parents, embryos were developed in $0-3.4 \%$ of their ovules. A total of 134 seedlings from nine backcross (or the similar cross) combinations were obtained through embryo culture. A seedling from the cross of $F_{1}$ as male parent flowered and proved to be a triploid. Amphidiploids could be used as pollen donors and eight $\mathrm{B}_{1}$ plants were produced from the cross of the amphidiploid of L.longiflorum $\times L$. henryi.

Three new interspecific hybrids in Lilium produced by embryo culture were introduced.
\end{abstract}

\section{Introduction}

The combined techniques of cut-style pollination with embryo culture in vitro allowed us to obtain a number of interspecific hybrids in Lilium which had not been produced by the usual crossing methods $(1$, $2,3,5)$. Some of the hybrids had horticulturally desirable characters such as disease resistance, flower color, fragrance, etc.. However, most of them were highly sterile and only a few $B_{1}$ progenies were obtained from those $F_{1}$. Next generations must be produced by overcoming these hybrid sterilities to attain such gene recombinations as to produce ideal horticultural hybrid lilies. For this purpose, the following methods were attempted.

1) Further use of embryo culture in the cross of $F_{1}$

2) Use of amphidiploids induced from $F_{1}$ The present paper reports these results and in addition, three new interspecific hybrids in Lilium produced by embryo culture are introduced.

\section{Materials and Methods}

Interspecific hybrids from 19 cross combinations were used in backcrosses or crosses

\footnotetext{
1 Received for publication January 4, 1982.
}

with the relatives. All of the hybrids were raised at our laboratory in recent years. Crosses were mostly made at the experimental field using the pollen either collected fresh or stored under refrigeration. Cutstyle pollination technique was applied again in those crosses. As soon as capsules started turning a little tan colored, they were harvested, sterilized in $70 \%$ alcohol and examined aseptically for embryos. The removed embryos were grown on Murashige and Skoog medium (11) under the same conditions as reported previously(2). Vermiculite was used as the transplant medium when seedlings were successfully obtained after 2-4 months culture. Two amphidiploid plants were induced from the hybrid $L$. longiflorum $\times$ L.henryi by $0.1 \%$ colchicine solution treatment of the scales one week after scaling(10). Amphidiploid 'Black Beauty'(L. speciosum $\times$ L.henryi) was donated by Mr. Woodriff, Oregon, U.S.A. Observation of meiotic chromosome pairing in PMCs of the amphidiploid was made by fixing in Newcomer's fluid(12) and iron aceto-carmine smearing. Somatic chromosome number, pollen fertility and pollen germination rate were examined in the same way as in the previous report(3). 


\section{Results and Discussion}

Crosses of $F_{1}$ as female parents

Many of the $F_{1}$ hybrids are completely pollen sterile and can not be used as male parents. However, when they were pollinated with the pollen from their parents or the relatives, especially with their paternal pollen, fertilization took place and a few seeds were produced in several hybrids $(3,5)$. From this observation, male parents (or the relatives) of the hybrids were mainly used as pollen donors in the present crosses. The results of the crosses are shown in Table 1. Embryos were produced in several hybrids including a triploid at an average low of 0.1 to an average high of 13.0 per capsule. These hybrid ovaries contained $234-426$ ovules so that the frequency of ovules forming embryos varied from $0.0-3.4 \%$. Almost all of the embryos were immature and were associated with none or liquid-semisolid abnormal endosperms. They were, however, often larger in size than those of $F_{1}$ hybrids and reached the stage of elongated boatshape. A total of 134 seedlings from nine backcross (or the similar cross) combinations were obtained through embryo culture.

A similar result of overcoming hybrid sterility by using the hybrid as the female parent was reported by Ronald and Ascher(13) in completely pollen sterile $L$. 'Black Beauty'. They gave two explanations for the possible reasons of this slight female functionality: 1) the difference in nutritive surroundings between female and male gametophytes and 2) mutual complement among deficient female genomes resulting from a specific megasporogenesis in Lilium, in which all four meiotic products participate in the formation of the female gametophyte.

In the interspecific cross, the failure of

Table 1. The results of the crosses of $F_{1}$ hybrids as female parents : cut-style pollination.

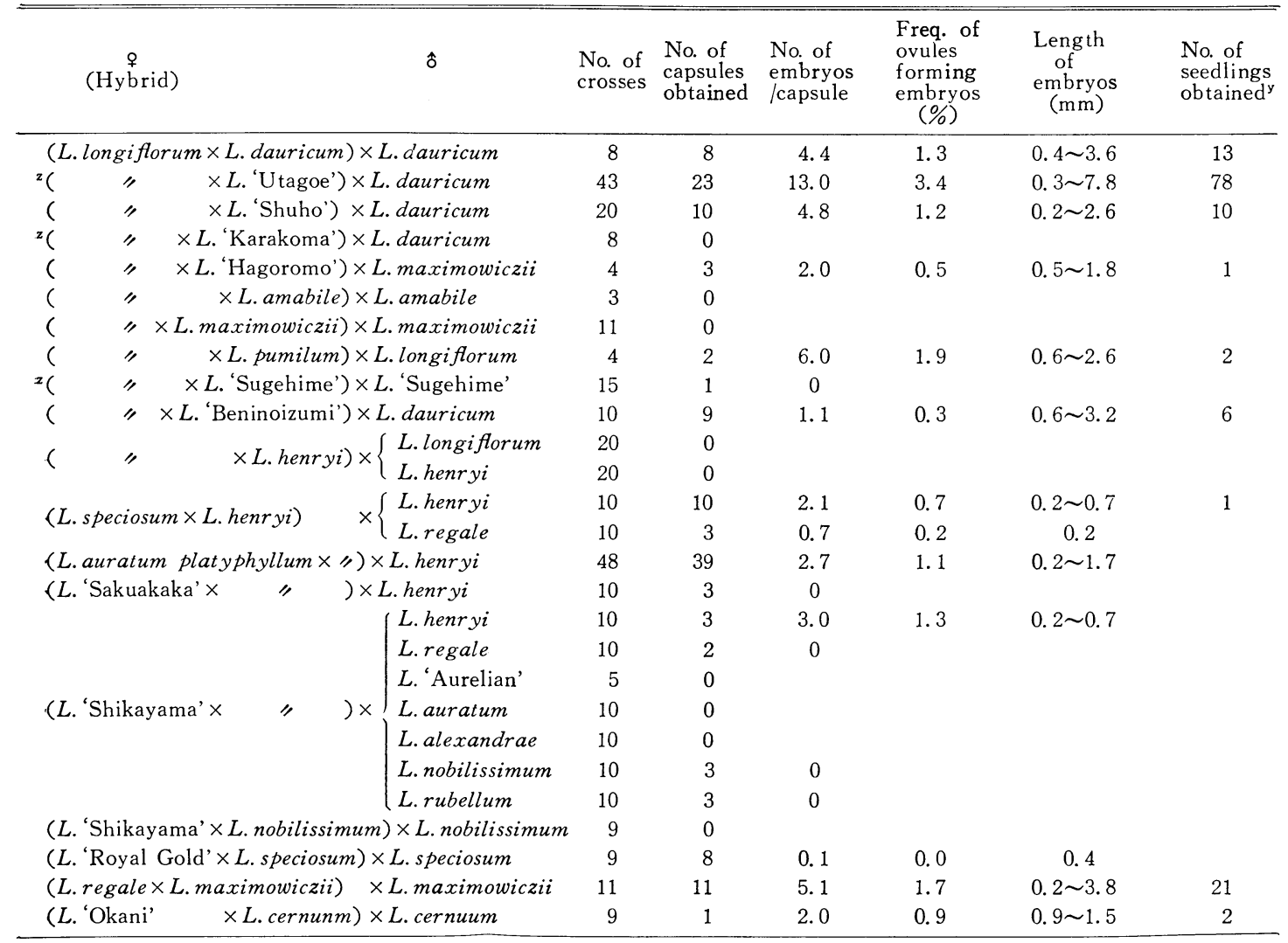

2 Triploid. y After embryo culture. 
Table 2. The results of the crosses of $F_{1}$ hybrids as male parents : cut-style pollination.

\begin{tabular}{|c|c|c|c|c|c|c|}
\hline 운 & (Hybrid) & $\begin{array}{l}\text { No. of } \\
\text { crosses }\end{array}$ & $\begin{array}{l}\text { No. of } \\
\text { capsules } \\
\text { obtained }\end{array}$ & $\begin{array}{l}\text { No. of } \\
\text { embryos } \\
\text { /capsule }\end{array}$ & $\begin{array}{l}\text { Length of } \\
\text { embryos } \\
(\mathrm{mm})\end{array}$ & $\begin{array}{l}\text { No. of } \\
\text { seedlings } \\
\text { obtained }\end{array}$ \\
\hline L. longiflorum & $\times($ L. longiflorum $\times$ L. maximowiczii $)$ & 30 & 0 & & & \multirow{14}{*}{3} \\
\hline L. longiflorum & \multirow{2}{*}{$\times($ L. longiflorum $\times$ L. 'Hagoromo') } & 5 & 0 & & & \\
\hline L. 'Hagoromo' & & 5 & 0 & & & \\
\hline L. henryi & \multirow{4}{*}{$\times($ L. auratum platyphyllum $\times$ L. henryi $)$} & 10 & 0 & & & \\
\hline L. 'Aurelian' & & 15 & 0 & & & \\
\hline L.auratum & & 5 & 2 & 0 & & \\
\hline L. speciosum & & 10 & 1 & 0 & & \\
\hline L. henryi & \multirow{6}{*}{$\times(L$. 'Shikayama' $\times$ L. henryi $)$} & 28 & 2 & 0 & & \\
\hline L. 'Aurelian' & & 64 & 8 & 1.8 & 1.4-mature & \\
\hline L. 'Royal Gold' & & 10 & 5 & 0 & & \\
\hline L. 'Shikayama' & & 5 & 0 & & & \\
\hline L. speciosum & & 10 & 0 & & & \\
\hline L. 'Sasaotome' & & 18 & 0 & & & \\
\hline L. 'Okani' & $\times($ L. 'Okani' $\times$ L. cernuum $)$ & 25 & 3 & 0.7 & $0.5 \sim 2.3$ & \\
\hline
\end{tabular}

endosperm development is caused by the disturbance of genetic balance in the genomic constitution $\mathrm{MMMM}+\mathrm{P}$ (polar nucleus + sperm nucleus) in the nuclei(7). (M: maternal genome, P: paternal genome) Endosperm failure in the backcross indicates that genetic imbalance exists in a similar fashion in the genomic constitution MMPP $+\mathrm{P}$.

Crosses of $F_{1}$ as male parents

Among the $F_{1}$ hybrids we obtained, some were found to be partially pollen fertile. Such five hybrids were used as pollen donors and crossed with their parents or the relatives. The results of the crosses are shown in Table 2. The pollen tube growth of those hybrids on artificial medium, was often abnormally short and was followed by tipbursting. This is suspected to be the primary cause of the very poor results. However, from one cross combination, $L$. 'Aurelian 7111 ' $\times(L$. 'Shikayama' $\times$ L. henryi $)$, a few matured seeds were obtained and they germinated without the aid of embryo culture. One of the seedlings flowered in 1980 and proved to be a triploid(Fig. 4, Table 7). The karyotype showed that two of the three genomes were derived from the male parent. Meiotic observation of the PMCs of the hybrid L.auratum platyphyllum $\times$ L.henryi showed the formation of unreduced gametes due to only equational division (unpublished). Probably, the hybrid $L$. 'Shikayama' $\times L$. henryi might have produced unreduced male gametes by a similar meiotic process. The

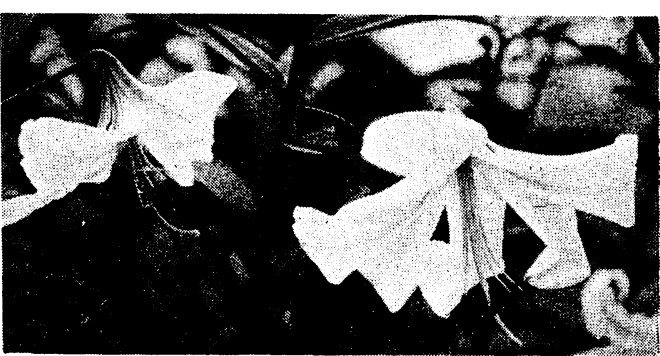

Fig. 1. Flowers of diploid (left) and amphidiploid (right) of L. longiflorum $\times$ L. henryi.

Table 3. Comparison of some characters between diploid and amphidiploid of $L$. longiflorm $\times$ L. henryi : The average of two plants, respectively.

\begin{tabular}{|c|c|c|}
\hline & $\begin{array}{l}\text { Diploid } \\
(2 \mathrm{n}=24)\end{array}$ & $\begin{array}{c}\text { Amphidiploid } \\
(2 \mathrm{n}=47,48)\end{array}$ \\
\hline Plant height & 155 & $158 \mathrm{~cm}$ \\
\hline Diameter of stem $^{z}$ & 13.5 & $16.5 \mathrm{~mm}$ \\
\hline No. of leaves ${ }^{y}$ & 90 & 63 \\
\hline No. of flowers & 8 & 5.5 \\
\hline Diameter of flower & 15.5 & $19.5 \mathrm{~cm}$ \\
\hline Flowering time ('81) & Aug. 2 & Aug. 4 \\
\hline Pollen : Fertility & 0 & $85.4 \%$ \\
\hline Germination rate $^{\mathrm{x}}$ & 0 & $11.6 \%$ \\
\hline
\end{tabular}

$z$ At the base.

y Below the lowest pedicel.

$x$ On the artificial medium.

pollen of this hybrid also successfully produced a number of progenies in the crosses with 'Oriental', the relatives of $L$. 'Shikayama', with the aid of embryo culture(van Tuyl, personal communication).

Crosses of amphidiploids

Two colchicine-induced amphidiploids of 
Table 4. The results of the crosses of amphidiploids : cut-style pollination.

\begin{tabular}{|c|c|c|c|c|c|c|}
\hline \& & $\hat{o}$ & $\begin{array}{l}\text { No. of } \\
\text { crosses }\end{array}$ & $\begin{array}{l}\text { No. of } \\
\text { capsules } \\
\text { obtained }\end{array}$ & $\begin{array}{l}\text { No. of } \\
\text { embryos } \\
\text { /capsule }\end{array}$ & $\begin{array}{l}\text { Length of } \\
\text { embryos } \\
\quad(\mathrm{mm})\end{array}$ & $\begin{array}{l}\text { No. of } \\
\text { seedlings } \\
\text { obtained }^{z}\end{array}$ \\
\hline \multicolumn{2}{|c|}{ Amphidiploid $\quad\{$ L.longiflorum } & 6 & 0 & & & \multirow{12}{*}{8} \\
\hline \multicolumn{2}{|c|}{ (L. longiflorum $\times$ L. henryi $) \times\{$ L. henryi } & 6 & 0 & & & \\
\hline \multirow{2}{*}{\multicolumn{2}{|c|}{ L. 'Black Beauty' $\quad \times\left\{\begin{array}{l}\text { L. speciosum } \\
\text { L.henryi }\end{array}\right.$}} & 5 & 0 & & & \\
\hline & & 5 & 5 & 0.8 & $0.2 \sim 0.3$ & \\
\hline L. longiflorum & \multirow{3}{*}{$\begin{array}{c}\text { Amphidiploid } \\
\times(\text { L. longiflorum } \times \text { L. henryi })\end{array}$} & 79 & 13 & 6.2 & $0.2 \sim 4.1$ & \\
\hline L. henryi & & 20 & 1 & 2.0 & 0.3 & \\
\hline L. 'Aurelian' & & 10 & 0 & & & \\
\hline L. speciosum & \multirow{4}{*}{$\times L$. 'Black Beauty' } & 58 & 13 & 0.6 & $0.3 \sim 1.1$ & \\
\hline L. 'Sakuakaka' & & 16 & 13 & 0.4 & $0.3 \sim 0.6$ & \\
\hline L. henryi & & 10 & 0 & & & \\
\hline L. 'Aurellan' J & & 10 & 0 & & & \\
\hline \multicolumn{2}{|c|}{ Between amphidiploids of L. longiflorum $\times$ L. henryi } & 7 & 0 & & & \\
\hline
\end{tabular}

${ }^{z}$ After embryo culture.

Table 5. Chromosome pairing frequency at metaphase I in PMCs of the amphidiploid $(2 \mathrm{n}=48)$ of L. longiflorum $\times$ L. henryi.

\begin{tabular}{llrrrrrrrrrrrrrrr}
\hline & \multicolumn{1}{c}{ Configurations/cell } & & & & Total \\
\hline Quadrivalent & $:$ & 1 & 1 & 1 & 1 & & & & & & & & \\
Trivalent & $:$ & 1 & & & & 1 & 1 & 1 & 1 & & & & & \\
Bivalent & $:$ & 20 & 22 & 21 & 20 & 22 & 21 & 20 & 19 & 24 & 23 & 22 & 21 & 20 & \\
Univalent & $:$ & 1 & & 2 & 4 & 1 & 3 & 5 & 7 & & 2 & 4 & 6 & 8 & \\
\hline Cells observed & 1 & 4 & 1 & 1 & 1 & 3 & 3 & 1 & 40 & 56 & 28 & 10 & 2 & 151 \\
\hline
\end{tabular}

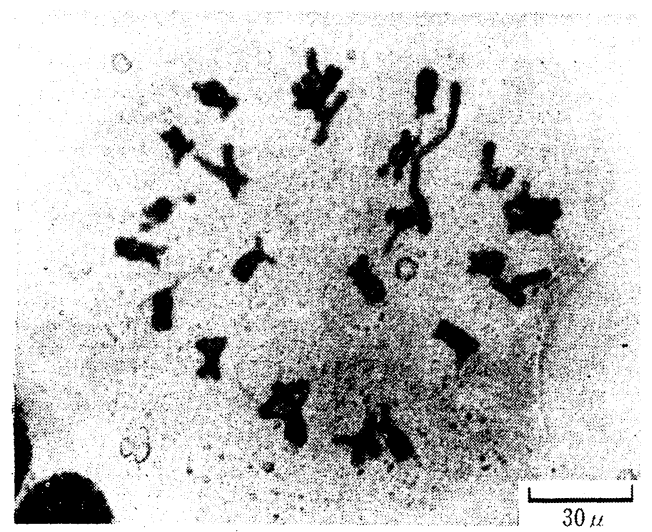

Fig. 2. Meiotic metaphase I in the PMC of the amphidiploid of L. longiflorum $\times$ L. henryi $(2 \mathrm{n}=48): 23$ bivalents +2 univalents.

L. longiflorum $\times$ L.henryi have chromosome numbers of 47 and 48. As compared with the original diploids, they show larger and more fleshy flowers and thicker stems, but fewer flowers and leaves(Fig, 1, Table3). Pollen fertility and some pollen germinating ability are restored. The results of the crosses using amphidiploids are shown in Table 4. It shows that amphidiploids from completely

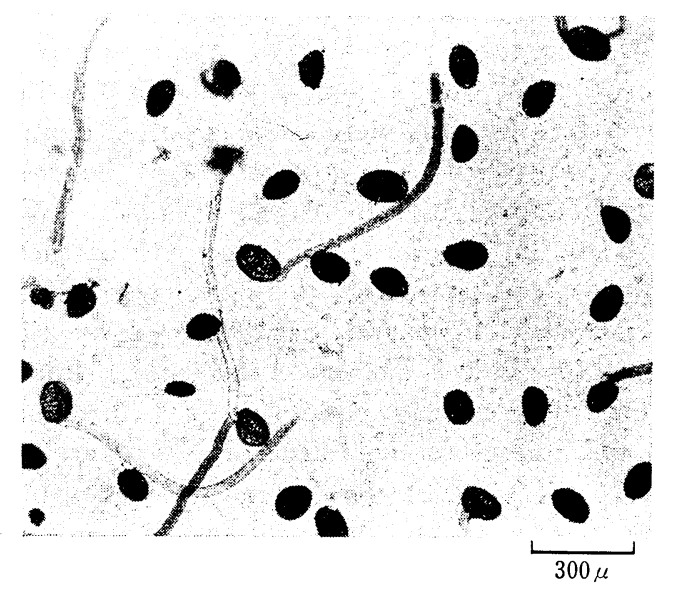

Fig. 3. Pollen germination of the amphidiploid of L. longiflorum $\times$ L. henryi on artificial medium. Note the short pollen tube growth and tip-bursting.

pollen sterile hybrids can be used as pollen donors especially when they are backcrossed with their female parents or the relatives, although embryo culture is still required to obtain seedlings. Eight $B_{1}$ plants were produced from the cross L. longiflorum $\times$ amphidiploid (L.longiflorum $\times$ L.henryi). 


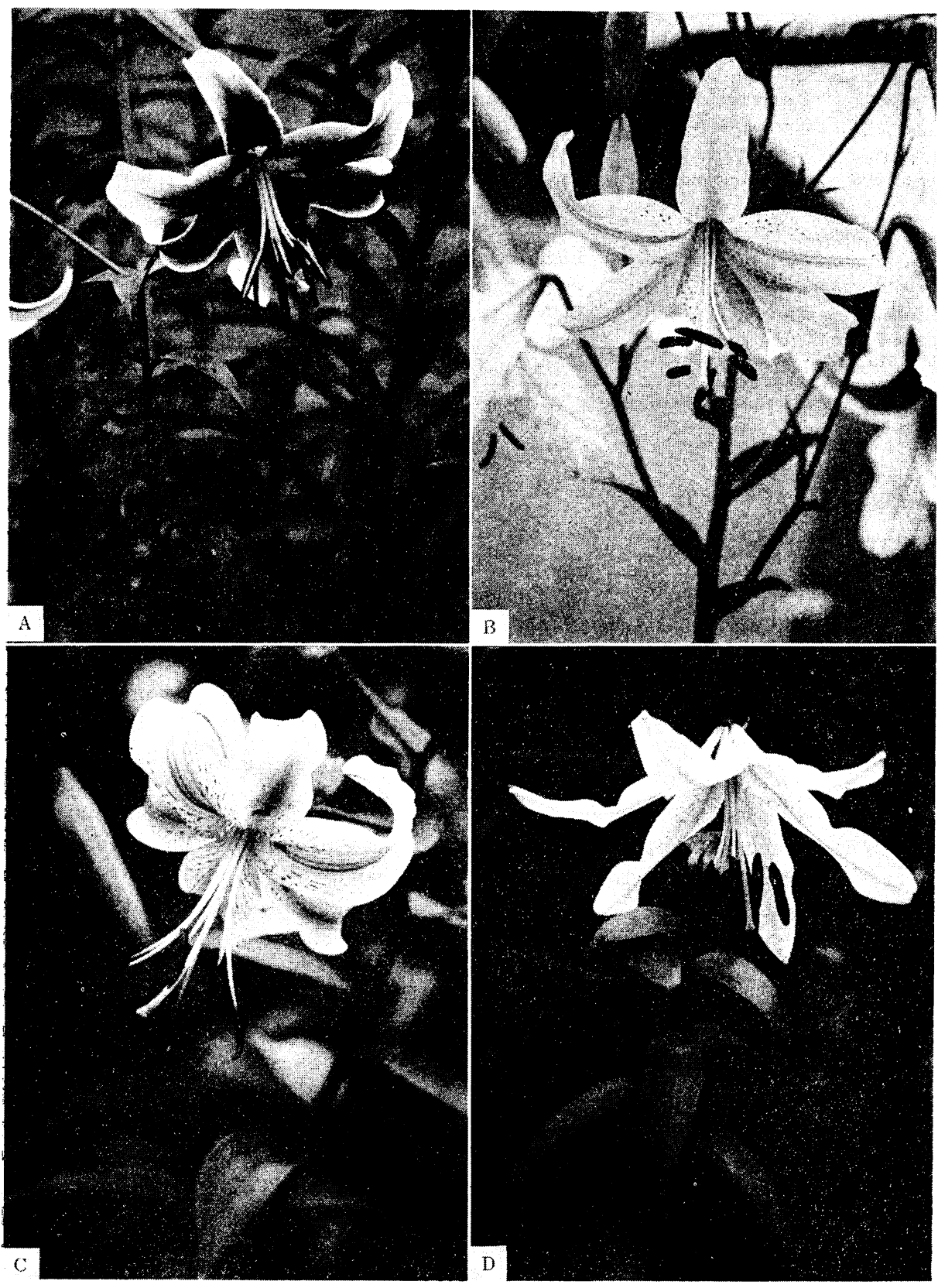

Fig. 4. Flowers of new interspecific hybrids in Lilium.

A : $L$. 'Aurelian 7111 ' $\times(L$. 'Shikayama' $\times$ L. henryi $)$

B : L. longiflorum $\times$ L. leichtlinii maximowiczii

C : L. 'Sakuakaka' $\times$ L. henryi

D : L. nobilissimum $\times$ L. henryi 
Table 6. Characters of new interspecific hybrids in Lilium.

\begin{tabular}{|c|c|c|c|c|}
\hline & $\begin{array}{c}\text { L. 'Aurelian 7111' } \\
\times \\
\text { (L. 'Shikayama' } \times \\
\text { L. henryi) }\end{array}$ & $\begin{array}{l}\text { L. longiflorum } \\
\times \\
\text { L. leichtlinii } \\
\quad \text { maximowiczii }\end{array}$ & $\begin{array}{c}\text { L. 'Sakuakaka'z } \\
\times \\
\text { L. henryi }\end{array}$ & $\begin{array}{c}\text { L. nobilissimum } \\
\times \\
\text { L. henryi }\end{array}$ \\
\hline Stem : color & Pale purplish brown & Light green & Pale purplish brown & Pale purplish brown \\
\hline Leaf : shape & Narrow lanceolate & Linear-lanceolate & Lanceolate & Lanceolate \\
\hline color & Light green & Green & Light green & Green \\
\hline Flower : facing & Sub-pendulous & Sub-pendulous & Sub-pendulous & Sub-pendulous \\
\hline type & Funnel & Recurved & Strongly recurved & Funnel \\
\hline diameter $(\mathrm{cm})$ & 17.3 & 13 & 10.5 & 18 \\
\hline color $^{\mathrm{y}}$ & Deep purplish red & Light orange & Pale yellow orange & Yellowish gray \\
\hline spots & Dark red & Purple & Brown & Pale purple \\
\hline pollen & Brown & Brown & Brown & Brown \\
\hline scent & Weakly sweet & None & Weakly sweet & Weakly sweet \\
\hline Flowering time & Late Jul. & Early Aug. & Mid Aug. & Mid Aug. \\
\hline
\end{tabular}

${ }^{2}$ L.auratum platyphyllum $\times$ L. speciosum

y Refer to 'Guide to color standard' (9).

Table 7. Chromosome numbers, pollen fertilities and pollen germination rates of new interspecific hybrids.

\begin{tabular}{|c|c|c|c|c|c|}
\hline \multicolumn{2}{|r|}{ Parents } & \multirow{2}{*}{$\begin{array}{c}\text { No. of } \\
\text { observation }\end{array}$} & \multirow{2}{*}{$\begin{array}{l}\text { Chromosome } \\
\text { No. }(2 \mathrm{n})\end{array}$} & \multicolumn{2}{|r|}{ Pollen } \\
\hline 운 & $\hat{\jmath}$ & & & $\begin{array}{l}\text { Fertility } \\
(\%)\end{array}$ & $\underset{(\%)}{\operatorname{Germination}}$ rate $^{\mathrm{z}}$ \\
\hline L. 'Aurelian 7111' & (L. 'Shikayama' $\times$ L. henryi) & 1 & 37 & 36.2 & 5.0 \\
\hline L. longiflorum & L. leichtlinii maximowiczii & 1 & 24 & 52.0 & 0.7 \\
\hline L. 'Sakuakaka' & L. henryi & 1 & 24 & 0 & 0 \\
\hline L. nobilissimum & L. henryi & 1 & 24 & 0 & 0 \\
\hline
\end{tabular}

${ }^{z}$ On the artificial medium.

However, when crosses were made with amphidiploids as female parents, no better results were obtained than in the crosses with the original diploids.

The result of the observation of meiotic chromosome pairing in PMCs of the amphidiploid of L.longiflorum $\times$ L.henryi is shown in Table 5 . Twenty six and a half percent of the PMCs (40 cells) had regular pairing configurations of 24 bivalents, and in $62.2 \%$ of the $\mathrm{PMCs}(94$ cells) $1-3$ pairs failed to show an association(Fig. 2). The formation of multivalents may indicate some chromosomal homology between the parental genomes(6). Almost regular nuclear divisions followed the metaphase I. Similar observations of restoration of chromosome pairing and the resultant fertile pollen were reported in the amphidiploid of $L$. 'Black Beauty' (8, 14). However, in spite of this observation, the pollen tube growth of the amphidiploid on artificial medium is found to be often abnormal (Fig. 3). This may indicate that both parental genomes are genetically illbalanced in pollens. This genomic imbalance and some incompleteness in chromosomal complements in pollens would be responsible for the tube growth abonormality and consequently, for the unexpected and very poor results of the crosses. A similar situation in female gametes might cause very poor results when amphidiploids were used as the female parents.

\section{Three new interspecific hybrids}

Three interspecific hybrids in Lilium were newly obtained by embryo culture(Fig. 4: BD). Among them, the hybrid of L. longiflorum $\times$ L.leichtlinii maximowiczii was raised by nurse culture(4) using normally developing L.longiflorum endosperm from the intraspecific cross as a nurse tissue. Their characters are generally intermediate between their parents in all of the three hybrids except for the red color on the flower in $L$. 'Sakuakaka' which is lost from the hybrid(Table 6). As L. 'Sakuakaka' has 
a gene responsible for anthocyanine pigement heterozygously, a genome devoid of the gene would participate in the cross. The hybrid L.longiflorum $\times$ L.leichtlinii maximowiczii has a pollen fertility of $52.0 \%$ and a slight pollen germination ability (Table 7 ). This will be the result of its relatively high extent of chromosome pairing at meiosis with an average of 7.5 bivalents/PMC(6). This may show some close genomic relationship between the parental species.

\section{References}

1. ASANO, Y. and H. MYOdo. 1977. Studies on crosses between distantly related species of lilies. I. For the intrastylar pollination technique. J. Japan. Soc. Hort. Sci. 46 : 59-65.

2. ASANO, Y. and H. MYODO. 1977. Studies on crosses between distantly related species of lilies. II. The culture of immature hybrid embryos. J. Japan. Soc. Hort. Sci. 46 : $267-273$.

3. ASANO, Y. 1978. Studies on crosses between distantly related species of lilies. III. New hybrids obtained through embryo culture. J. Japan. Soc. Hort. Sci. $47: 401-414$.

4. ASANO, Y. 1980. Studies on crosses between distantly related species of lilies. IV. The culture of immature hybrid embryos 0.3$0.4 \mathrm{~mm}$ long. J. Japan. Soc. Hort. Sci. $49: 114-118$.
5. ASANO, Y. 1980. Studies on crosses between distantly related species of lilies. V. Characteristics of newly obtained hybrids through embryo culture. J. Japan. Sco. Hort. Sci.! $49: 241-250$.

6. ASANO, Y. 1982. Chromosome association and pollen fertility in some interspecific hybrids of Lilium. Euphytica 31 : in press.

7. DOWRICK, G. J. and S. N. BRANDRAM. 1970. Abnormalities of endosperm development in Lilium hybrids. Euphytica 19 : 433-442.

8. EMSWEller, S. L. and J. UHRING. 1966. Lilim x'Black Beauty'-Diploid and amphidiploid. Lily Yb., R. H.S. $29: 45-47$.

9. JAPAN COLOR INSTITUTE. 1954. Guide to color standard. Nihonshikisai-sha Ltd. Tokyo.

10. KUniShige, M. and Y. HiRATA. 1975. Induction of polyploidy in Lilium. Bull. Hort. Res. Stat. (Kurume) : 5-8.

11. Murashige, T. and F. Skoog. 1962. A revised medium for rapid growth and bioassays with tabacco tissue cultures. Physiol. Plant. $15: 473-497$.

12. NewCOMER, E. H. 1953. A New cytological and histological fixing fluid. Science $118: 161$.

13. RONALD, W. G. and P. D. ASCHER. 1976. Lilium x'Black Beauty'-A Potential bridging hybrid in Lilium. Euphytica $25: 285-291$.

14. UHRING, J. 1966. Concerning lily chromosome terminology. Lily Yb., N. Am. Lily Soc. $19: 125-133$.

\title{
ユリの種間雑種の雑種不稔性の克服
}

\author{
浅 野義人 \\ 北海道大学農学部 606 札幌市
}

\footnotetext{
摘 要

ユリの種間雑種の雑種不稔性を打破するために, 次の 方法が採られた．1） $\mathrm{F}_{1}$ の交配に抽ける，再度の胈培盖 の利用，2）複二倍体の作成. $F_{1}$ を母親とした交配にお いて, 幾つかの組合せで, $0.0 \sim 3.4 \%$ の泼珠で胚が形成 された. 9 戻し交雑（或はそれに近い）組合せから，泼 培養を経て, 合計 134 個体が得られた. $\mathrm{F}_{1}$ を父親とし

た交配からの 1 個体が開花し，これは三倍体であった。 複二倍体は花粉親として用い得ることが認められ, テッ ポウユリメキカノコュリの複二倍体との交雑から 8 個体 の $\mathrm{B}_{1}$ が得られた.

肧培養により作られた， 3 組合せの新しいユリの種間 雑種が紹介された.
} 